\title{
From pandemic to infodemic: Bias information of covid-19 and ethical consideration among Indonesian youtuber
}

\author{
Rani Prita Prabawangi* \& Megasari Noer Fatanti \\ Universitas Negeri Malang, Malang, Indonesia
}

\begin{abstract}
Since WHO declared the COVID-19 outbreak a global pandemic in March 2020, the spread of information related to this virus has become increasingly unstoppable. Indonesia is not only facing a health crisis due to the spread of COVID-19, but also false information going around on a large scale on social media. The Indonesian government has identified more than 1400 hoaxes related to COVID-19 on social media. Based on the consideration of the novelty element of the phenomenon, there are three YouTube channels that discuss COVID-19. This study uses discourse analysis and literature review method, with a corpus of data gathered through searching digital archives. The outcomes of the analysis will later be linked to the concept of free speech and journalism ethics. In the end, this research seeks to find a common formula for addressing the COVID-19 infodemic phenomenon, especially what comes about in the social media ecosystem in Indonesia.
\end{abstract}

Keywords: COVID-19, infodemic, misinformation, social media

\section{INTRODUCTION}

The new coronavirus pandemic - hereafter known as COVID-19, was first identified in Wuhan, Hubei, China, after several cases of mysterious pneumonia that have spread rapidly since December 2019 (Huang et al. 2020). Seeing the extent of the spread of the virus that is increasingly widespread in various countries, WHO as the world health authority finally established a global pandemic status for COVID-19 in March 2020. Shortly after the status has been determined, information pandemics are spread around the world, both by mainstream media (television, newspapers, radio and magazines) and by the Internet. Since COVID-19 is a new type of coronavirus and the exact cause of it is not yet known, the public is actively seeking information via the Internet-both on social media and on video sharing sites (YouTube). As a medium that is affordable and provides abundant information, social media has become a new space for people to share health information with each other, especially regarding COVID-19. Based on the pre-research results, some informants said that they prefer to seek information about COVID-19 through social media rather than mainstream media, because of the fast and massive nature of social media (Brennen et al. 2020).

For example, information on health protocols (keep your distance, wash your hands, and wear a mask), people actually know first information spread on the Internet - one of which is YouTube. With this information, the public can prevent and reduce the spread of the virus and reduce the burden on health care institutions in a country. Therefore, it is very important to understand the information the public receives about the coronavirus, particularly during a pandemic. The opinion refers to a previous health studies showing that YouTube has the potential to spread misinformation (Madathil et al. 2015).

\footnotetext{
*Corresponding author: rani.prita.fis@um.ac.id
} 
This paper aims to analyze the extent to which Indonesian YouTubers are responsible for the false information that he has already spread through their YouTube channels. While some of the videos have been removed by YouTube, the public continues to believe that the information that is being disseminated is true.

\section{LITERATURE REVIEW}

\subsection{YouTube is a source of health information}

There is a growing body of evidence that e-health, Internet and social media-based interventions can improve the prevention and management of chronic diseases and lifestyle-related chronic-disease risk factors (Oldenburg et al. 2015). YouTube, one of the most popular video-sharing sites on the Internet, is increasingly being used as a platform to disseminate health information and may be a tool to assist in education regarding the prevention and management of type 2 diabetes among South Asian Internet users (Madathil et al. 2015). Despite this, the quality of health information online has been a concern; a systematic review revealed that studies have documented the availability of both high- and low-quality information (Eysenbach et al. 2002). Searching for health information online is typically classified as a low-risk activity, but a review has documented cases of harm as a result of online misinformation (Crocco et al. 2002). A systematic review of 18 studies investigating health-care information on YouTube through 2013 found that YouTube contains videos that portray misleading information that contradict evidence-based reference standards. On the top, Youtube accounts such 'Lisan Hamba' and Deddy Corbuzier are able to reach more than five and three million people. While at the same time, the top reach website -Beritasatu.com- can only reach three thousand people.

\subsection{Misinformation during pandemic COVID-19}

This pandemic causes us not only have to deal with virus outbreak but also an outbreak of disinformation about COVID-19 (OECD 2020). Due to the novelty of the virus and the limited information of it, a lot of people choose to share any information they have through social media especially when new cases are found. Research finds that a meaningful spatio-temporal relationship exists between information flow and new cases of COVID-19 (Singh et al. 2020). Study in Malaysia demonstrates a desire among students to share credible and correct information with their family and friends through social media (Hashim et al. 2020). This positive result was also found in Indonesia where social media culture can educate the public about COVID-19 (Sampurno et al. 2020). The preliminary data gathered indicates that while discussions about myths and links to poor quality information exist, their presence is less dominant than other crisis specific themes (Singh et al. 2020).

However, some research also finds worrying conditions about misinformation of Covid-19. In Indonesia, despite the overflowing information about Covid-19 is, some groups of people are found to be misinformed and uninformed about the origin, transmission and preventive measures (Nasir et al. 2020). It is not surprising, because even credible sources of information are available, the ability to reach audiences is far lower than the less incredible one. Other than the source, the information about Covid-19 itself is concerning. One of misinformation that is often talked about on social media is the conspiracy behind Covid-19. Some Indonesia youtubers agree on conspiracy theory although their scenarios of conspiracy are different from one another and lack of scientific data (Wahyudi \& Akalili 2020). Research on conspiracy theory shows contradictory narrative from the Chinese and the American versions. Social media in China tells of America's efforts to make Covid a biological medium warfare or biological warfare against China (Mishra 2020). On the other hand, the American version accuses China of having lost control of testing biological weapons in its lab so that America holds China accountable for this pandemic (Mishra 2020). 


\section{METHODS}

This research using a discourse analysis and literature study from various research about misinformation, pandemic Covid-19, and information belief. Others data gathered from three channel of Indonesian's YouTuber, namely Deddy Corbuzier, ANJI, and The Hermansyah A6. The research phase begins with sampling carried out by searching for videos on YouTube by entering the keywords "COVID-19", "Indonesian coronavirus", "COVID-19 conspiracy" and searching for viral YouTuber accounts in the mass media and activating the search filter for video sequences based on relevance. From the initial sample size of 50, the author selected 6 videos and then 2 videos were selected taking into account the number of subscribers, viewers, comments, and duration of discussion of an issue. The next stage is analyzing the video using discourse analysis with an in-depth search of YouTube policies related to video uploads to the theme of COVID-19 and the snares of the ITE Law in Indonesia over the dissemination of misinformation by the YouTuber.

\section{RESULT AND ANALYSIS}

\subsection{Indonesian's YouTuber and misinformation of COVID-19}

Like many other social media platforms, YouTube is powered by a search algorithm and recommender system based on the principle of "collaborative filtering," designed to help users navigate the millions of pieces of content available on its site (Bendersky et al. 2014). Based on the analysis of the findings from two videos taken from the Dunia MANJI and Deddy Corbuzier channels respectively, it can be classified as content that contains junk and conspirational elements. Videos relaying verifiably false information or conspiracy theories about the origin, transmission and treatment of the coronavirus; xenophobia and denial of mainstream scientific positions as assessed against WHO public advisory information. The first video, for example, was quoted from the Dunia MANJI channel containing an interview with Hadi Pranoto, who was introduced as a professor and microbiologist containing information related to the Covid-19 drug, which received comments from 305 people and has been shared more than a thousand times. However, this information has proven to be inaccurate, disrupting the public and hampering the management of the COVID-19 pandemic in Indonesia (Garnesia 2020a)

The second video, taken from channel Deddy Corbuzier with title "CORONA HANYA SEBUAH KEBOHONGAN KONSPIRASI!!!” (CORONA IS JUST A CONSPIRACY LIE!!!) by interviewing a public figure named Young Lex. It has been viewed 10 million times and has 8.52 million YouTube subscribers. In the video, Deddy Corbuzier and Young Lex talk about COVID-19 instead of the deadly virus and the vaccine is a global human depopulation strategy. These allegations are based on unreliable sources, because both individuals are unable to provide scientific evidence of their statements (Garnesia 2020b)

\subsection{Ethics in social media environment}

The nature of user generated content (UGC) owned by social media - one of which is YouTube, frees the audience to express themselves, although there are also some rules that both media content producers and connoisseurs need to follow. In this context, YouTube is designed as a democratic media, by providing opportunities for each individual to broadcast himself, both audio and visual, and to build relationships with viewers who are accommodated in their YouTube account channel (Allocca 2018). YouTube creators compete to show off different materials and finally exclude quality control. Eventually, two videos that are the unit of analysis in this paper show that (1) the mainstream media has a big challenge in clarifying the misinformation that has already spread through social media; (2) there needs to be a regulation in Indonesia that regulates YouTube digital media content, especially health issues; (3) support and involvement of literacy activists, government and citizens to monitor YouTube content that violates information policies. 


\section{SUMMARY}

Social media with the nature of user generated content (UGC) which opens up space and makes it easier for individuals to produce information and share it, has become an opening for misinformation, especially during the current pandemic. The phenomenon of Indonesian YouTubers uploading interview videos discussing COVID-19 is recognized by some people as having good intentions to provide information to the public in simple language, but unfortunately information that has not been verified by a credible source has already been disseminated and apparently contains misinformation. People who use social media as a reference about COVID-19 are in fact getting an incomplete understanding, especially when the information is claimed to be untrue.

The dissemination of health information, especially about Covid-19 is poor, and in particular the lack of clarification and verification, makes it even more difficult for the public to distinguish between truth and falsehood. This means that health care consumers who obtain information about COVID-19 on YouTube are poorly informed. This may lead to misconceptions about the treatment, prevention and general characteristics of the virus. We recommend that people verify the facts they learn on YouTube with more reliable sources of information such as conventional mass media, health care professionals, or online updates by WHO or Ministry of Health of the Republic of Indonesia.

As a final recommendation, we hope to see policies around the dissemination of health information through social media. Although YouTube is the platform that initiated the regulation, it appears that it has not been properly implemented within the Indonesian context. We see the need for commitment and participation from many parties, such as literacy activists, journalists and netizens, to establish rules related to health misinformation.

\section{REFERENCES}

Allocca, K. (2018) Videocracy: How YouTube is changing the world... with double rainbows, singing foxes, and other trends we can't stop watching. Bloomsbury Publishing.

Bendersky, M. et al. (2014) 'Up next: retrieval methods for large scale related video suggestion', in Proceedings of the 20th ACM SIGKDD international conference on Knowledge discovery and data mining, pp. 17691778.

Brennen, J. S. et al. (2020) 'Types, sources, and claims of COVID-19 misinformation', Reuters Institute, 7, pp. 1-3.

Crocco, A. G., Villasis-Keever, M. and Jadad, A. R. (2002) 'Analysis of cases of harm associated with use of health information on the internet', Jama, 287(21), pp. 2869-2871.

Eysenbach, G. et al. (2002) 'Empirical studies assessing the quality of health information for consumers on the world wide web: a systematic review', Jama, 287(20), pp. 2691-2700.

Garnesia, I. (2020a) 'Menilik Disinformasi Hadi Pranoto tentang COVID-19', tirto.id. Available at: https://tirto.id/menilik-disinformasi-hadi-pranoto-tentang-covid-19-fVqn.

Garnesia, I. (2020b) 'Periksa Fakta "Konspirasi COVID-19" ala Deddy Corbuzier \& Young Lex', tirto.id. Available at: https://tirto.id/periksa-fakta-konspirasi-covid-19-ala-deddy-corbuzier- young-lex-eRVi.

Hashim, S. et al. (2020) 'Students' intention to share information via social media: A case study of COVID-19 pandemic', Indonesian Journal of Science and Technology, 5(2), pp. 236-245.

Huang, C. et al. (2020) 'Clinical features of patients infected with 2019 novel coronavirus in Wuhan, China', The lancet, 395(10223), pp. 497-506.

Madathil, K. C. et al. (2015) 'Healthcare information on YouTube: a systematic review', Health informatics journal, 21(3), pp. 173-194.

Mishra, S. (2020) 'The Post-Pandemic World Order: Nine Pointers', New York: IndraStra Global.

Nasir, N. M., Baequni, B. and Nurmansyah, M. I. (2020) 'Misinformation related to COVID-19 in Indonesia', Jurnal Administrasi Kesehatan Indonesia, 8(2), pp. 51-59.

OECD (2020) 'Combatting COVID-19 disinformation on online platforms', OECD Policy Responses to Coronavirus (COVID-19), (July), pp. 1-7. Available at: http://www.oecd.org/coronavirus/policyresponses/combatting-covid-19- disinformation-on-online-platforms-d854ec48/. 
Oldenburg, B. et al. (2015) 'Using new technologies to improve the prevention and management of chronic conditions in populations', Annual review of public health, 36, pp. 483-505.

Sampurno, M. B. T., Kusumandyoko, T. C. and Islam, M. A. (2020) 'Budaya media sosial, edukasi masyarakat, dan pandemi COVID-19', SALAM: Jurnal Sosial dan Budaya Syar-i, 7(5).

Singh, L. et al. (2020) 'A first look at COVID-19 information and misinformation sharing on Twitter', arXiv preprint arXiv:2003.13907.

Wahyudi, G. S. and Akalili, A. (2020) 'Narrative of Covids as Conspiracy on Youtube', JCommsci-Journal Of Media and Communication Science, 1(1), pp. 26-37. 